\title{
Direct action self-help (DASH) groups in UK flood risk management
}

\author{
Jonathan $\operatorname{Simm}^{1, a}$ \\ ${ }^{1} H R$ Wallingford, Howbery Park, Wallingford, Oxfordshire OX12 8JT, United Kingdom
}

\begin{abstract}
This paper presents an analysis of the nature and effectiveness of community direct action self-help (DASH) groups and includes a case study analysis of a river conveyance management group and a sea wall management group. DASH groups are found to be motivated by the need to deal with increasing flood risk in the face of reduced public funding, alongside sense of stewardship and community solidarity. Channel maintenance work by a DASH group can be effective and efficient at reducing some aspects of local fluvial flood risk for lower order flood events. Maintenance of existing sea walls by a DASH group may be less efficient because of the need for significant expenditure on materials and only efficacious if the engineering is quality-controlled; its longer term effectiveness is also limited by sea level rise. DASH groups require nurture to be sustainable but can deliver community benefits. Professional FCRM coordination and support of DASH activity was examined using a case study of an Environment Agency (EA) area coordinator and comparisons with alternative approaches. Support of DASH groups by FCRM professionals was found to be essential to avoid unwise activities and involves not only controlling consents, but also providing advice on the nature and extent to which DASH activity might be appropriate and arranging practical support and seed-corn funding. The most effective form of DASH facilitation requires a quality and quantity of involvement that cannot readily be supplied by dispersed arrangements from a number of individuals.
\end{abstract}

\section{Introduction}

UK post war flood management has been identified [1] as having passed through at least three phases:

- 1940s to 1970s: Land drainage and food security

- 1980s to mid-1990s: Flood defence

- mid-1990s onwards: Flood risk management.

As part of the move to Flood and Coastal Risk Management (FCRM) in the UK, a slow 'social turn' has been identified towards wider involvement of local communities, including increasing stakeholder engagement and 'co-delivery' [1]. There appear to be three drivers behind this turn:

- The need to adapt to increasing flood risk arising from changes in climate.

- The need to integrate FCRM policy, both in the UK and more widely in Europe, with the sustainable development agenda, especially in regard to involving the public in the social (and environmental) aspects of developing policies, strategies and schemes [2-6].

- A wider trend towards empowering communities at a local level to help themselves, originally from the perspective of enabling local voices to set agendas, but more recently being promoted by the present UK government's Big Society agenda [7] in the context of the need to reduce public expenditure.

\footnotetext{
${ }^{\mathrm{a}}$ Corresponding author: j.simm@hrwallingford.com
}

As well as delivering citizen needs and giving them a greater voice, citizen involvement in activities such as flood risk management has the potential to strengthen 'social capital' - the networks of relationships in our communities - by creating "new spaces for recognition, reconnection, conversation and debate" [8]. The appropriate level of citizen participation, however, remains an open question and discussion often revolves around the need to find a "middle ground between the individualism of the market and the collectivism of the state" [9].

In her classic "ladder" of citizen participation (see Figure 1), Arnstein [10] argued that it is possible to conceive of forms of participation which are not genuine, being either symbolic or even at worst manipulative. On the other hand, the "top" of Arnstein's ladder of citizen participation is not necessarily the best place to be, as it may imply [11] a degree of abrogation of governmental and professional responsibility.

\begin{tabular}{|c|c|c|}
\hline 8 & $\begin{array}{l}\text { Citizen control (or self- } \\
\text { governance) }\end{array}$ & \multirow{3}{*}{$\begin{array}{l}\text { Degrees of } \\
\text { citizen power } \\
\text { (or participation) }\end{array}$} \\
\hline 7 & Delegated power & \\
\hline 6 & Partnership (or co-operation) & \\
\hline 5 & Placation & \multirow{3}{*}{$\begin{array}{l}\text { Degrees of } \\
\text { tokenism } \\
\text { (or symbolic participation) }\end{array}$} \\
\hline 4 & Consultation & \\
\hline 3 & Informing & \\
\hline 2 & Therapy & \multirow{2}{*}{$\begin{array}{l}\text { Levels of non-participation } \\
\text { "contrived to substitute for } \\
\text { genuine participation" }\end{array}$} \\
\hline 1 & Manipulation & \\
\hline
\end{tabular}

Figure 1 Sherry Arnstein's ladder of citizen participation (after Arnstein [10]) 
Furthermore, some users may not wish to be involved at the higher levels of the ladder, or may want to jump on and off the ladder [12].

The 2007 summer floods in England were particularly catalytic in driving a more participatory approach, with greater citizen involvement promoted by Sir Michael Pitt [13] in his subsequent review of the flooding for the UK government. In a wide ranging review with 92 recommendations, Pitt put ordinary people at the centre of policy. Two of his recommendations are of particular note in the context of this paper

- "RECOMMENDATION 70: The Government should establish a programme to support and encourage individuals and communities to be better prepared and more self-reliant during emergencies, allowing the authorities to focus on those areas and people in greatest need."

- "RECOMMENDATION 24: The Government should develop a scheme which allows and encourages local communities to invest in flood risk management measures."

In the period 1998 to 2015, but particularly in the wake of the summer 2007 floods, Direct Action Self-Help (DASH) groups started to emerge in small, generally rural, communities where there was little prospect of state assistance. Their aim was focussed on the maintenance and improvement of FCRM assets in order to reduce the flood risk their communities were facing. This paper evaluates the extent to which such groups are viable and can be an efficacious, efficient and effective means of managing and monitoring FCRM assets.

\section{Research methods}

The research methods employed in the evaluation included a combination of semi-structured interviews along with two detailed case studies. Analytical tools employed included textual analysis of interview transcriptions and engineering and economic analyses of the activities of the DASH groups at the case study sites. The locations of the potential or actual groups interviewed are shown in Figure 2.

Case study locations were in Oxfordshire in central southern England and at an estuarine location in Hampshire on the south coast of England, and the author visited these sites regularly. Developments were recorded in photographs and the journals of the author and those prepared by the leaders of the DASH groups. In addition to evaluating the groups themselves, a further case study was conducted of the role of a DASH group coordinator employed by the Environment Agency in Oxfordshire.

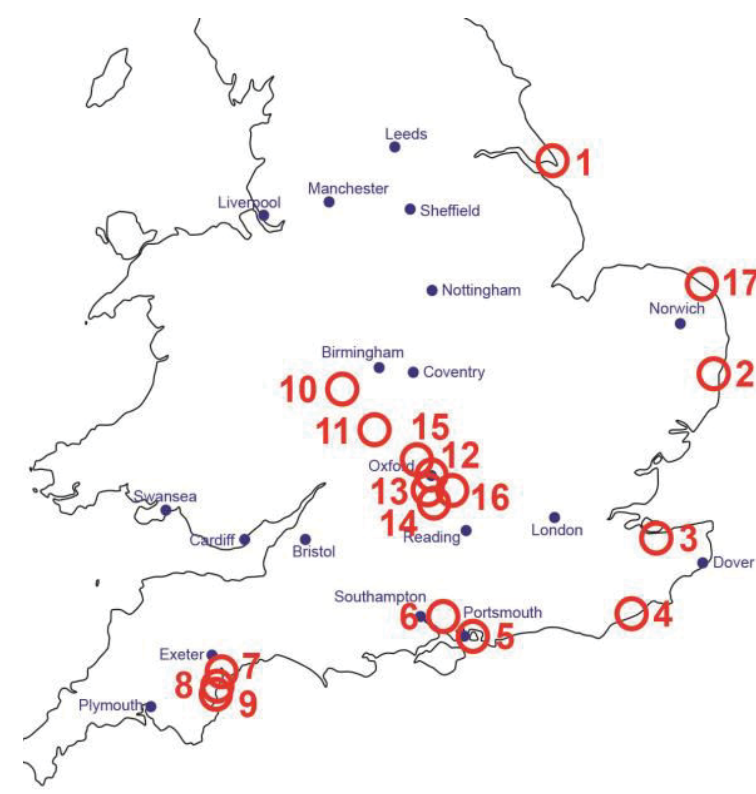

Figure 2. Locations of self-help groups contacted

\section{Overview of DASH groups}

\subsection{Motivations}

As well as the need to 'do something' to deal with increasing flood risk in the face of reduced public funding and altruistic motives, emergence of 'grass roots' [14] DASH groups was found to be motivated a sense of stewardship of place $[11,15]$ and community solidarity [16]. These latter motivations have been seen to operate together in a self-reinforcing way [17]. Such motivations have also specifically been found in surveys of volunteering activity generally in both the UK [18] and in the US [19]. As a whole, the set of motivations can be seen to mirror (see Figure 3) Maslow's [20] hierarchy of human needs.

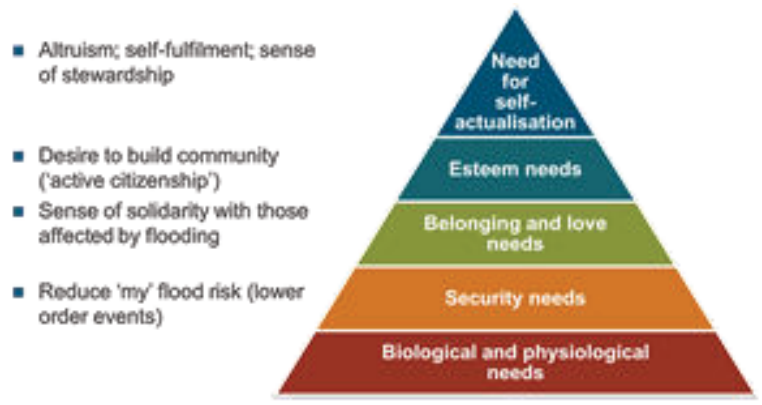

Figure 3. DASH group motivations alongside Maslow's [20] hierarchy of needs

\subsection{Leadership}

DASH groups frequently form around one or more motivated individuals who take the lead, but with a mandate or constitution linked to the relevant form of local democracy (e.g. parish council or residents' association). The leaders then convince others to "act as if the group exists" [14], often "stepping into" a leadership role as the most suitable and willing person 
[21]. Thus they are able to network and mobilise support for action [22], making and using local contacts and can be quite professional in their approach:

“...we see paperwork as a weapon. You [professionals in FCRM] throw lots of arguments about - we can respond to that. That's not a problem. So we're not frightened of bureaucracy if you like. So we've done our own risk assessments. We have a method procedure for all our work." [DASH group leader, Sept 2009]

\subsection{Conceptual framework}

Use of contextual literature and the analysis of the semi-structured interviews enabled a conceptual framework (Figure 4) to be developed of the different dimensions, contextual aspects and motivations for DASH activity and its support by government.

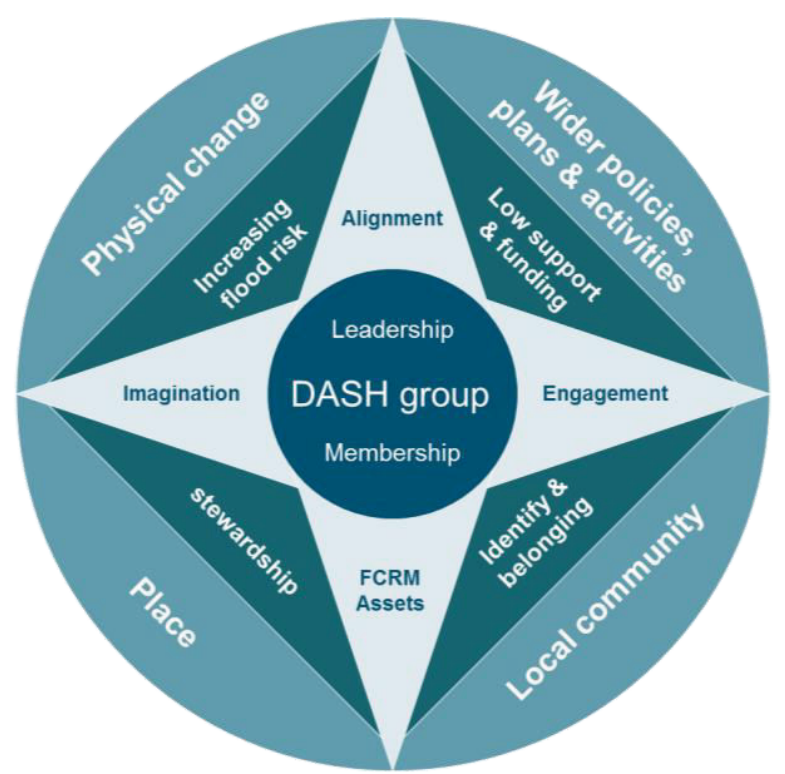

Figure 4. Conceptual model for DASH groups in FCRM.

Motivations for action are shown in the flat dark blue triangles pointing towards the DASH group in the centre of Figure 4. In the top right, a part of the wider policies, plans and activities of government organisations involved in FCRM includes the aspect of limited availability of public support and funding. This motivator can be viewed both in two ways: negatively, in that the lack of conventional full public funding for FCRM works may motivate DASH activity to commence, but also positively in that advice and seed-corn funding from public (or other) sources may help to trigger commencement of DASH activity.

The remaining motivators are associated with each of the remaining contextual elements:

- physical change and increasing flood risk becomes a directly perceived motivator, particularly after catalytic flood events;

- the desire for identity and belonging is linked to the local community; and

- the geography and environment of the place which offers DASH group members a motivation for stewardship not just of the physical FCRM assets but also of the wider environment in which they are situated.

Around the star in the outer circle of Figure 4 lies the context within which the DASH group is situated and which sets up the motivations just described. Within this the following elements can be identified: a world of physical change in which flood risk may be increasing; the place and the local community within which the DASH group is situated; and the wider policies, plans and activities of government and non-government organisations both professional and voluntary.

In the central circle of Figure 4 lies the developing DASH group with its leader and members and their associated knowledge, skills and expertise. The points of the star represent the dimensions of the group: Imagination, Engagement, Alignment and the FCRM assets themselves. Each of the dimensions of the DASH group is located nearest to the motivations and contextual elements with which they are most closely associated

Considering each of these dimensions in turn, the following may be noted in relation to Figure 4:

- the FCRM assets lie as a feature of the place and local community and form one part of the community spaces and structures;

- the Imagination of the DASH group, which concerns the past and the future and possibilities arising with and without direct action, lies within the context of both the local community vision for their place and the challenges of future physical change including climate change (e.g. sea level rise), morphological change and asset deterioration;

- the Engagement of the DASH group, representing its relationships, interactions, practices and shared histories of learning lies within the tensions of the aspirations of the local community and a broad range of wider policies, plans and activities and the individuals and organisations involved, including landowners and FCRM professionals; and

- the Alignment of the group lies between the constraints of both the physical change taking place in the wider natural and human-made environment and the wider policies, plans and activities. The latter might include Shoreline Management Plans or Catchment Flood Management Plans. Such alignment is important to avoid wasted work by the group and adverse impacts on others, ideally with a vision to follow the sustainability principle of "Think global; act local".

\subsection{Working process}

The activities making up the DASH process are described in flow chart form in Figure 5. The flow chart has been developed using Checkland's [23] soft systems methodology and makes clear the importance of 


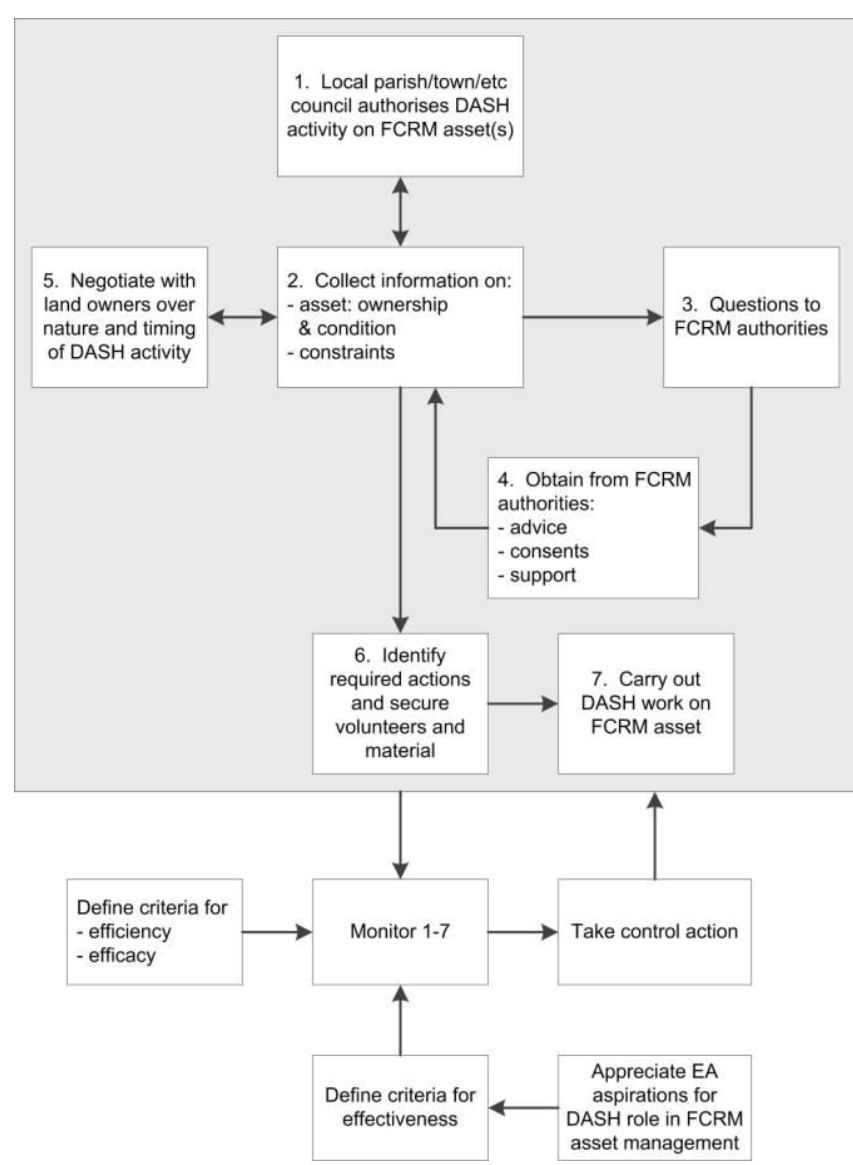

Figure 5. DASH group activity sequence

the following:

- support and authorisation from the local parish council or residents' association to set up the DASH group;

- interactions with landowners and the relevant authorities to gather information and gain advice support and consent for any activity;

- securing the resources and support of volunteers to progress the DASH activity.

Figure 5 also identifies that at any point the process could be stopped through lack of support from people and organisations (e.g. landowners, FCRM authorities) or through lack of volunteers or resources. Thus continual communication with all these parties and clear identification of, and consent for, the physical objectives of the work becomes essential and emerges as a significant difference between DASH activity in FCRM and other common grassroots associational activities such as support or study groups.

\subsection{Liability and insurance}

A major concern of both professionals and volunteers in regard to DASH groups has been the health and safety of volunteers especially when operating in or over water. However, groups not only carry out risk assessments and provide their volunteers with protective equipment (e.g. waders, life jackets), but are also insured under the terms of a scheme made available through the British Trust for Conservation Volunteers, since 2012 known as the Conservation Volunteers.

\section{Case studies}

The conceptual model and the effectiveness of such groups was tested by two case studies of river conveyance and sea wall management DASH groups.

\subsection{Channel maintenance group}

The channel maintenance DASH group selected for study was the Hanneys Flood Group in Oxfordshire, UK, which carries out management of the Letcombe Brook as it flows through the villages of East and West Hanney. The group commenced work in the summer of 2008 and is viewed the Environment Agency to have led the way locally in setting down a benchmark of good practice for such groups.

The main activities carried out by the group are weed and trash clearance from the Letcombe Brook (Figure 6), using ubiquitous 'gardening-style' expertises. The first clearance of the brook in 2008 after a long period of neglect led to a significant fall (between $0.2 \mathrm{~m}$ and $0.6 \mathrm{~m}$ ) in low-flow water conditions and the group has been working since to maintain these lower water levels. Other activities have included the localised raising of a low spot in the river bank levels, installation of by-pass pipes and lowering of a control weir at a mill structure by $100 \mathrm{~mm}$. The work of the group continues.

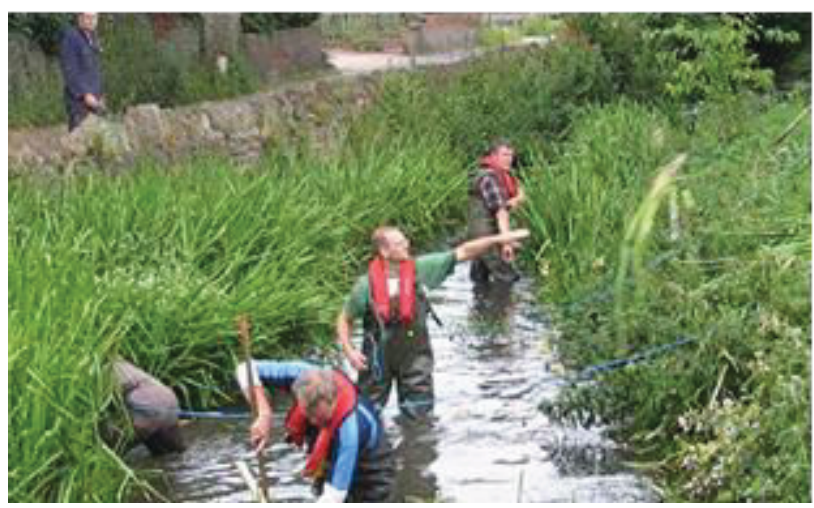

Figure 6. Weed clearance in Letcombe Brook, summer 2008

Analysis using a 1D flow model of the Letcombe Brook has demonstrated that significant reductions in water levels are also obtained during a 20 year flood event, except to the immediate upstream side of control structures, where increases in water levels of about $0.1 \mathrm{~m}$ are evident. Using this information as a starting point, approximate assessments of flooding and damages indicate that annual benefits of the order of $£ 17,000$ per annum have been delivered by the work of the group. This can be compared with initial out of pocket expenses for the group in the first year of $£ 8000$ and subsequent maintenance costs of about $£ 1500$ per annum. (Costs have largely been funded by EA and the local council.) Comparison of whole life benefits and costs suggests a benefit to cost ratio of about 12:1. This is significantly higher than would have been the case if the work had been procured in a conventional manner in which case the benefit to cost ratio would only have been about $3: 1$ and would not have passed the threshold for funding. 
Thus channel maintenance work by DASH groups can be effective and efficient at reducing some aspects of local fluvial flood risk, especially for more frequent, less severe flood events. Other useful conclusions that can be drawn from this case study are as follows:

- River channel maintenance work by DASH groups can be efficacious in reducing flood water levels although an effect of channel maintenance may be to slightly raise water levels close to control structures.

- Economic analysis of case study data indicates that the reduced out-of-pocket costs of DASH group work can deliver flood risk reduction associated with rivers efficiently and to an acceptable benefit to cost ratio in comparison with conventionally funded work. Accurate estimates of avoided flood risk require a level of modelling rarely justified.

- Effectiveness of DASH groups in reducing local flood risk is limited by:

$\circ$ the heritage of pre-existing infrastructure such as river weirs and drainage systems; and

$\circ$ the reduced effect of channel management for more severe storms.

- Improvements in flood risk by DASH channel management do not necessarily deliver reduced insurance costs. They thus contrast unfavourably with insurance reactions to property-level flood resistance and resilience measures.

\subsection{Sea wall maintenance group}

The group selected here was the North East Hayling (Island) Residents Association (NEHRA)which manages tidal sea defences in Chichester Harbour, Hampshire, on the south coast of England. The group sought and obtained permission from the Environment Agency to carry out repairs to a dilapidated flood embankment which protects the villages of Northney and Tye and the associated farmland to the north east of Hayling Island. Deficiencies in the flood embankment included erosion of the waterward face towards Chichester Harbour and irregular settlement and erosion of the embankment crest. The waterward face had previously been protected by an adhoc mixture of measures and the repair approach selected by the group was to use hessian bags filled with dry-mix concrete, stacked in a bonded fashion and secured by driven dowels of reinforcing steel (Figure 7).

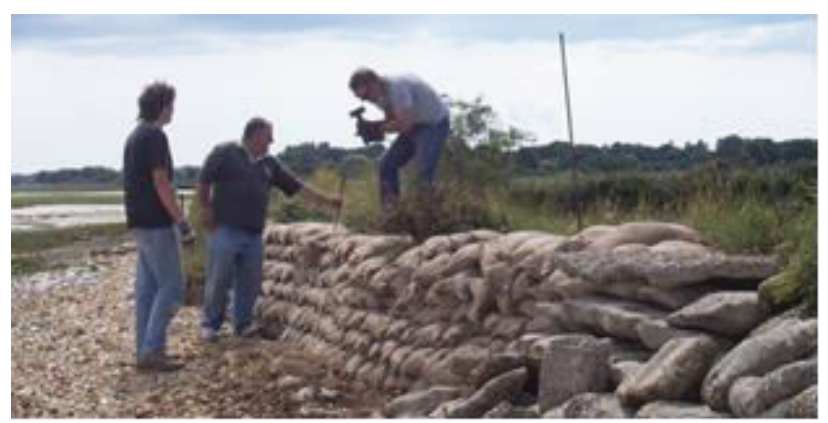

Figure 7. Estuary wall repairs, Hayling Island, summer 2009
The DASH group saw the wall and the grazing marsh it protected as important to the community, not only because of it being a farming community, but because of the wall

- maintaining behind it over the grazing marsh a storage volume tide for water draining from the villages during extreme rainfall events when these might occur at high tide; and

- providing an important permissive path for the villagers to enjoy Chichester Harbour.

At the time of carrying out the work in summer 2009, the major focus was ensuring that the repair work was appropriately bonded into the embankment. However, it subsequently transpired that, due to a lack of construction skills, inadequate quantities of cement had been added into the dry mix and thus unfortunately the concrete in the bags deteriorated very quickly (in 3 years) and in the 2013-14 winter storms much of the new concrete bagwork was lost.

The group did not receive any funding from the EA or the local authority but the materials costs incurred amounted to between $£ 2000$ and $£ 3000$ which were covered by the farmers who owned the land on which the sea wall was located. Because of their lack of confidence in the efficacy of further work, they would not provide any further funding for the group to carry out maintenance or indeed allow them to arrange it another way. Hence the group did not continue its work.

One of the reasons for lack of public funding is that the majority of the calculable avoided damages relate to loss of agricultural production leading to benefit to cost ratios for conventional schemes less than 1:1. Had the DASH group work continued it is estimated that repairs would have been needed roughly every 3 years. On this basis it is estimated that on materials cost alone the DASH group could have delivered a long term benefit to cost ratio of about $4: 1$, significantly less than the riverine project of 12:1, but with no definable avoided property damage losses to take into account on the benefits side

Maintenance of existing sea walls by DASH groups is less efficient because of the need for significant expenditure on materials and only efficacious if the engineering is quality-controlled; its longer term effectiveness is limited by sea level rise. In particular, the following issues are of key importance:

- Good quality repair work is required if DASH activity is to be contemplated as an efficacious solution.

- Materials costs associated with sea wall repairs can be significant, especially if the work has to be repeated or extended on a regular basis. Thus repairs cannot necessarily be justified on grounds of efficiency, even though they may be cheaper than equivalent professional interventions.

- Sea level rise poses significant challenges to the long-term effectiveness of existing sea defences; maintenance of such defences without raising and strengthening and even relocating the defence line may only be attractive to local communities looking for short-term benefit. 


\section{Professional support for DASH groups}

From the previous section, it is clear that whilst DASH groups can deliver significant community benefits, they require nurture to deliver sustainable improvements in the performance of FCRM assets. In particular, DASH groups need FCRM professional support (see Figure 8) in relation to:

- obtaining improved understanding of local flooding mechanisms;

- receiving practical support in the development of flood management strategies (avoiding unwise strategies) and the skills to deliver them;

- receiving consent for their activities to proceed;

- financial support of seed-corn funding for materials and equipment.

They may also need related support in connection with developing emergency flood plans and/or generating improvements to the local environment. The Environment Agency has an interest in ensuring all these things take place, given a national policy target to "work with people and communities to create better places" [24].

To this end, professional FCRM coordination and support of DASH activity was examined using a case study comparing the role of a temporary (3 year) EA area coordinator with subsequent more distributed support arrangements. The differences are summarised in Table 1, with the most effective form of DASH facilitation requiring a quality and quantity of involvement that cannot readily be supplied by dispersed arrangements from a number of individuals.

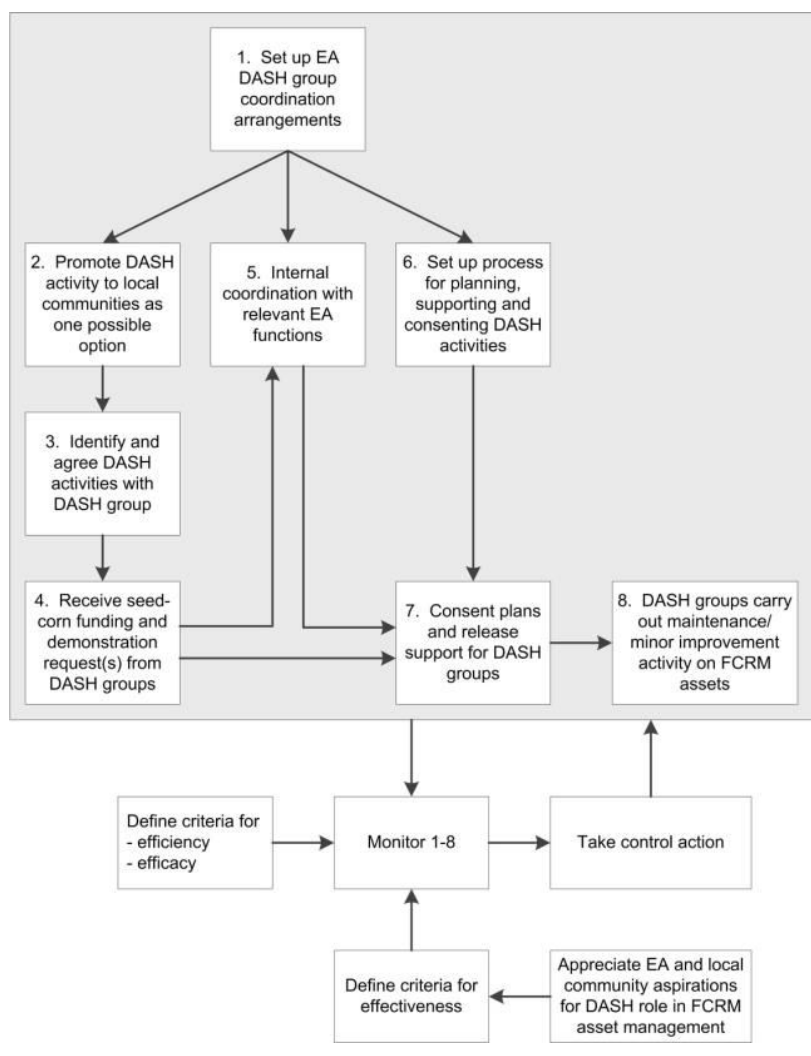

Figure 8. EA activity sequence to support DASH groups

\begin{tabular}{|c|c|c|}
\hline $\begin{array}{l}\text { Aspe } \\
\text { role }\end{array}$ & $\begin{array}{l}\text { ess of a } \\
\text { up } \\
\text { or role }\end{array}$ & $\begin{array}{l}\text { Effectiveness of } \\
\text { current distributed } \\
\text { arrangements within } \\
\text { EA }\end{array}$ \\
\hline $\begin{array}{lr}\text { Point } & \text { of } \\
\text { contact } & \text { for } \\
\text { DASH } & \\
\text { groups. } & \\
\end{array}$ & $\begin{array}{l}\text { Effective } \\
\text { appreciated by } \\
\text { groups }\end{array}$ & $\begin{array}{l}\text { DASH groups would } \\
\text { still like single point of } \\
\text { contact. (EA do not } \\
\text { consider necessary.) }\end{array}$ \\
\hline $\begin{array}{l}\text { Experience } \\
\text { exchange } \\
\text { between } \\
\text { DASH } \\
\text { groups } \\
\end{array}$ & $\begin{array}{l}\text { Experience sharing is } \\
\text { integral to role and can } \\
\text { be organised and } \\
\text { encouraged. }\end{array}$ & $\begin{array}{l}\text { Information exchange } \\
\text { not presently being } \\
\text { organised }\end{array}$ \\
\hline $\begin{array}{l}\text { Proactive } \\
\text { community } \\
\text { contact }\end{array}$ & $\begin{array}{l}\text { Limited, as it is } \\
\text { difficult to make } \\
\text { contacts without some } \\
\text { kind of lead. }\end{array}$ & $\begin{array}{l}\text { Limited, but } \\
\text { communities at highest } \\
\text { risk are targeted. }\end{array}$ \\
\hline $\begin{array}{l}\text { ing } \\
\text { for } \\
\text { iity }\end{array}$ & $\begin{array}{l}\text { Allows time for } \\
\text { explanation } \\
\text { communities of the } \\
\text { range of available } \\
\text { options and support } \\
\text { for the initiation of } \\
\text { subsequent action. } \\
\end{array}$ & $\begin{array}{l}\text { PSO team meet } \\
\text { communities and } \\
\text { explain range of } \\
\text { options available but } \\
\text { have more limited } \\
\text { time than group } \\
\text { coordinator to do so. } \\
\end{array}$ \\
\hline $\begin{array}{l}\text { Sharing } \\
\text { experiences } \\
\text { to assist } \\
\text { DASH } \\
\text { group start- } \\
\text { up and } \\
\text { activity and } \\
\text { managing } \\
\text { expectations }\end{array}$ & $\begin{array}{l}\text { Key principles of } \\
\text { channel and defence } \\
\text { management can be } \\
\text { shared and expounded. } \\
\text { Experience sharing } \\
\text { can be proactive. }\end{array}$ & $\begin{array}{l}\text { Principles shared by } \\
\text { PSO team in an initial } \\
\text { meeting. APT provide } \\
\text { detailed advice on } \\
\text { hands-on aspects like } \\
\text { channel maintenance } \\
\text { techniques. Proactive } \\
\text { experience-sharing is } \\
\text { missing. }\end{array}$ \\
\hline $\begin{array}{l}\text { Resourcing: } \\
\text { funding and } \\
\text { in-kind } \\
\text { support }\end{array}$ & $\begin{array}{l}\text { Hands-on support can } \\
\text { provided for: } \\
\text { modelling/designs, } \\
\text { utility searches, and } \\
\text { liaison with } \\
\text { conservation officers. } \\
\text { Block funding can be } \\
\text { sought and joint } \\
\text { arrangements made } \\
\text { with EA maintenance } \\
\text { workforce. } \\
\end{array}$ & $\begin{array}{l}\text { Provision of } \\
\text { resourcing present but } \\
\text { fragmented. DASH } \\
\text { groups have to } \\
\text { proactively obtain any } \\
\text { resources and support } \\
\text { from the EA } \\
\text { themselves. Joint } \\
\text { arrangements with EA } \\
\text { workforce are made. }\end{array}$ \\
\hline $\begin{array}{l}\text { ation } \\
\text { ssional } \\
\text { gues }\end{array}$ & $\begin{array}{l}\text { Balanced single point } \\
\text { of contact approach } \\
\text { allows the positive } \\
\text { aspects of DASH } \\
\text { activity to come } \\
\text { through } \\
\text { ignoring the problems. }\end{array}$ & $\begin{array}{l}\text { Role split between } \\
\text { PSO and APT. There } \\
\text { is no single internal } \\
\text { champion for DASH } \\
\text { activity. }\end{array}$ \\
\hline $\begin{array}{l}\text { Organising } \\
\text { consents } \\
\text { including } \\
\text { conservatio } \\
\mathrm{n} \text { issues }\end{array}$ & $\begin{array}{l}\text { Simplified consenting } \\
\text { procedure set up. } \\
\text { Emphasises value of } \\
\text { hand working in } \\
\text { reducing habitat/ } \\
\text { biodiversity damage. }\end{array}$ & $\begin{array}{l}\text { Simplified consenting } \\
\text { procedure continues. } \\
\text { PSO team happy with } \\
\text { way it is operating. } \\
\text { DASH groups feel less } \\
\text { supported. } \\
\end{array}$ \\
\hline $\begin{array}{l}\text { Support to } \\
\text { DASH } \\
\text { groups } \\
\text { during } \\
\text { action }\end{array}$ & $\begin{array}{l}\text { Arranging /conducting } \\
\text { site visits during work; } \\
\text { preparing community } \\
\text { magazine material; } \\
\text { arranging advice from } \\
\text { EA maintenance } \\
\text { workforce. }\end{array}$ & $\begin{array}{l}\text { Advice } \\
\text { demonstrations from } \\
\text { EA maintenance } \\
\text { workforce are given. } \\
\text { Other support during } \\
\text { action is patchy. }\end{array}$ \\
\hline
\end{tabular}

Table 1. Effectiveness of DASH group coordination by EA 
In addition to this day to day guidance from professional FCRM coordinators, DASH groups have also requested documentary guidance on both procedures and engineering matters and this remains a clear need.

\section{Defra Flood Resilience Community pathfinder scheme: implications for DASH}

Comparisons with the Defra Flood Resilience Community Pathfinder scheme (2013-15) are relevant in the UK context as this explored a much wider range of community participation and actions than DASH. The Defra scheme was aimed at enabling and stimulating communities at significant or greater risk of flooding to improve the community's overall resilience to flooding, by:

- enhancing flood risk management and awareness;

- improving the community's financial resilience;

- delivering sustained improvements having potential for wider application.

An evaluation of the scheme [25] was carried out in order to:

- report on the progress made by the individual pathfinder projects;

- report on the results and impacts of the scheme as a whole; and

- provide evidence to ensure that lessons can be learnt from the pathfinder scheme.

The evaluation of the scheme adopted a mixed methods approach, using qualitative and quantitative social research techniques to collect, synthesise and analyse evidence, with Cutter et al.'s [26] model of resilience used as a theoretical base. This includes 5 elements of resilience: social, community, economic, institutional and infrastructural. In Cutter et als view their model is 'mainly an appraisal of community response and recovery capacity and the extent to which physical infrastructures that house, transport and produce goods and services for society may be particularly vulnerable to sustaining damage and likely economic losses' (Cutter et al., 2010: 9). But under this heading the Defra funded review [26] also included actions that communities take to increase their resilience to flooding through physical measures (e.g. property-level protection measures, flood storage, highway drainage), and draw the following conclusions:

- having the right infrastructure makes communities better able to manage and cope with flooding and is key to building community capacity;

- much individual infrastructure, e.g. property-level protection, works better as part of a community resilience process;

- it is important to work out what is needed with all involved in order to install infrastructure that a community can manage.

The final conclusion is an important one in the context of DASH work and reinforces the findings of the study presented in this paper, in particular:
- Some types of infrastructure are more practical for communities to manage than others (e.g. channels are easier to maintain than walls as 'gardening' is a more ubiquitous expertise than 'building'). This relates both to existing infrastructure and infrastructure that may be in the planning process

- Community-based maintenance programmes must be developed collaboratively with communities in order to understand how community resources and expertise could match the types of asset present or required.

\section{Conclusions}

Communities have a 24/7 range of needs/aspirations for their infrastructure, not just during floods, that relate to both people and place.

Communities may be happy to "do something" to mitigate flood risk, recognising they may have more impact on more frequent but less severe floods.

Direct Action Self-Help (DASH) groups can manage infrastructures for which they have the appropriate skills and capabilities, carrying out monitoring, maintenance and some repairs.

DASH group management of assets requires practical guidance from FCRM professionals (including on governance, physical processes and engineering) both in documentary form and in real time. They also need modest financial support.

\section{References}

1. Nye, M., Tapsell, S. \& Twigger-Ross, C. (2011). New social directions in UK flood risk management: moving towards flood risk citizenship? Journal of Flood Risk Management, 4:288-297.

2. UNECE (1998) Convention on access to information, public participation in decision-making and access to justice in environmental matters. Aarhus, Denmark: United Nations Economic Commission for Europe

3. Water Framework Directive (2000). European Community

4. European Community (2003). Common Implementation Strategy for the Water Framework Directive (2000/60/EC). Guidance document No. 8: Public participation in relation to the Water Framework Directive.

5. Directive on the assessment and management of flood risks (2007). European Community. 2007/60/EC

6. Environmental Impact Assessment Directive (2011). European Union.

7. Williams, R. (2011) Getting to the heart of the Big Society. WEM - the Environment Magazine. London: Chartered Institute of Water and Environmental Management

8. Putnam, R., Feldstein L. \& Cohen D. (2005). Better together: restoring the American community. New York: Simon \& Schuster. 
9. Day, G. (2006) Community and everyday life. Abingdon: Routledge.

10. Arnstein, S. R. (1969). A ladder of citizen participation. Journal of the American Institute of Planning, 35, 216-224

11. Carr, A. (2002). Grass roots and green tape. Principles and practice of environmental stewardship. Sydney: The Federation Press,

12. Tritter, J. \& McCallum, A (2006). The snakes and ladders of user involvement: moving beyond Arnstein. Health Policy, 76, 156-168.

13. Pitt, M. (2008) The Pitt Review: Learning lessons from the 2007 floods. London: Defra.

14. Smith, D. H. (2000) Grassroots associations. Thousand Oaks, CA: Sage.

15. Gooch, M. (2005). Voices of the volunteers: an exploration of the experiences of catchment volunteers in coastal Queensland, Australia. Local Environment, 10(1), 5-19.

16. Sarason, S. (1974). The psychological sense of community: perspectives for community psychology. San Francisco: Jossey Bass.

17. McMillan, D. \& Chavis D. (1986). Sense of community: a definition and theory. Journal of Community Psychology, 14, 6-23.

18. Rochester, C., Ellis-Paine A. \& Howlett S. (2010) Volunteering and society in the 21st Century. Basingstoke: Palgrave Macmillan.

19. Einolf, C. \& S. Chambré. (2011) Who volunteers? Constructing a hybrid theory. Int. J. Nonprofit and Voluntary Sector Marketing, , 16, 298-310.

20. Maslow, A. (1943) A theory of human motivation. Psychological Review, 50, 370-396.

21. Ockenden, N. \& Hutin, M. (2008) Volunteering to lead: a study of leadership in small, volunteer-led groups. London: Institute for Volunteering Research.

22. Wenger, E. (1998) Communities of practice: learning, meaning and identity. Cambridge: Cambridge University Press.

23. Checkland, P. \& Poulter, J. (2006) Learning for action: a short definitive account of soft systems methodology and its use for practitioners, teachers and students. Chichester: John Wiley.

24. Environment Agency (2011). Corporate Plan 201115. Bristol: Environment Agency.

25. Twigger-Ross, C., Orr, P., Brooks K., Sadauskis, R., Deeming, H., Fielding, J., Harries, T., Johnston, R., Kashefi, E., McCarthy, S., Rees, Y. and Tapsell, S. (2015) Flood Resilience Community Pathfinder Evaluation: Final Evaluation Report: London: Defra, October 2015

26. Cutter, S.L., Barnes, L., Berry, M., Burton, C., Evans., E., Tate, E., and Webb, J. (2008) A placebased model for understanding community resilience to natural disasters, Global Environmental Change, 18, 598-606. 